\title{
The Latvian Marriage Law 1918-1940 Betwixt and Between the Poles of Conflicting Moral Values
}

\author{
Dr. jur. Philipp Schwartz \\ Turku, Finland \\ E-mail:philschw@aol.com
}

The article looks at the Latvian marriage law during the period of 1918-1940, and how it copes with being betwixt and between the poles of conflicting moral values. The article sheds light on the discussions in the newly established Republic of Latvia regarding its marriage law, which was to be created and the development of the codification work took culminating in the Latvian Civil Code of 1937. Additionally, it draws parallels with the contemporary discussions in Latvia between the supporters of a more traditional conservative and a more modern liberal family and marriage law.

Keywords: marriage law, confessional and civil marriage, individual and common interests, patriarchal marriage law, gender equality, divorce law.

\section{Contents}

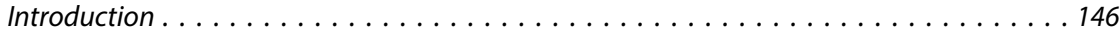

1. Confessional v. Civil Marriage Law . . . . . . . . . . . . . . . . . . . . . . . . . . . 149

2. Individual v. Common Interest . . . . . . . . . . . . . . . . . . . . . 150

3. Patriarchal Marriage Law v. A Marriage Law Based on Gender Equality . . . . . . . . . 151

4. Till Death Do Us Part v. A Modern and Liberal Divorce Law . . . . . . . . . . . . . . . 153

Summary . . . . . . . . . . . . . . . . . . . . . . . . . . . . . . . . 154

Sources . . . . . . . . . . . . . . . . . . . . . . . . . . . . 155

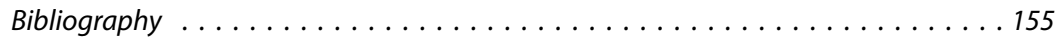

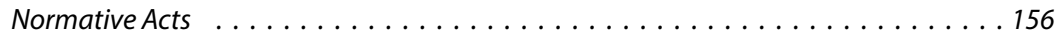

Case Law . . . . . . . . . . . . . . . . . . . . . . . . . . . 157

\section{Introduction ${ }^{1}$}

The legal system of a country mirrors the country's value system. A legal system is based on and at the same time defines the common values of a country and its society. But what happens when these values change, and a society can no longer agree on a common understanding? Does in such case the legal system automatically has to (be) change(d) to once more arrive at a common understanding?

The marriage law is constantly in between, on the one hand, the established value and legal system and its proponents who want to protect and conserve it, whereas on the other hand, those who consider the legal and value system

1 All translations from German and Latvian into English by the author of this article. 
"outdated" and no longer reflecting the changes in society and, thus unsuitable. The decision by the Constitutional Court of Latvia of 12 November $2020,{ }^{2}$ the subsequent public and political discussion and the initiative to amend Art. 110 of the Constitution ${ }^{3}$ are a good proof of this conflict and the disagreement between those supporting a more narrow, traditional definition of the family and those supporting a more open, flexible definition of the family. Interestingly enough, the very same Article 110 had been amended only 15 years ago specifying that that marriage is the union of a man and a woman. ${ }^{4}$

This conflict between preserving the existing order and introducing changes is not a modern phenomenon. It is well known in those fields of law which are closely linked to people's values and beliefs, to concepts of life and changes in societal views and realities. It has happened already more than 100 years ago when the Republic of Latvia elaborated its own civil law after having declared its independence in 1918. The Latvian marriage law specifically is a very rewarding case study. ${ }^{5}$

After Latvia had declared its independence on 18 November 1918, it was decided that, for the time being, the laws which were in force until the beginning of the October Revolution 1917 and the takeover by the Bolsheviks will be further applied as long as they were not in contradiction to the Latvian state order. ${ }^{6}$ However, it became quite obvious that the presently applicable law due to various reasons (social and local particularism, casuistry and need of modernisation) had ceased to be suitable for the newly independent Republic of Latvia. ${ }^{7}$ It was therefore decided to elaborate a new and own Latvian Civil Code. While the work on the all-encompassing Latvian Civil Code took nearly 20 years until it was adopted on 28 January 1937, legislative groundwork was done during the years in between. ${ }^{8}$

2 Judgement of the Constitutional Court of Latvia of 12 November 2020 in case No. 2019-33-01 "Par Darba likuma 155. panta pirmās daḷas atbilstību Latvijas Republikas Satversmes 110. panta pirmajam teikumam" " "On the conformity of Art. 155 First Paragraph Labour Law with Art. 100 First Sentence of the Constitution of the Republic of Latvia”]. Available: https:/www.satv.tiesa.gov.lv/wp-content/ uploads/2019/12/2019-33-01_Spriedums-3.pdf [last viewed 03.02.2021].

3 Nacionālā apvienība rosina Satversmes grozijumu, lai nostiprinātu giimenes jēdzienu [The National Alliance proposes an amendment to the Constitution to strengthen the notion of family]. Available: https://www.nacionalaapvieniba.lv/aktualitate/nacionala-apvieniba-rosina-satversmes-grozijumulai-nostiprinatu-gimenes-jedzienu/ [last viewed 06.02.2021].

4 Grozijums Latvijas Republikas Satversmē [Amendment to the Constitution of the Republic of Latvia]. Latvijas Vēstnesis, No. 1, 03.01.2006. Available: https://www.vestnesis.lv/ta/id/124957 [last viewed 07.02.2021]. The original draft Art. 114 which was at the end not adopted back in 1922 read "The marriage is based on the principle of gender equality and is protected by the state as foundation of the family".

5 While this article is focusing on the Latvian marriage law between 1918 and 1940, an overview on the evolution and development of the marriage law in Latvia from the $10^{\text {th }}$ to the $20^{\text {th }}$ century is provided by Lazdiňš, J. Die Entstehung und Entwicklung des Eherechts in Lettland [The evolution and development of the marriage law in Latvia]. In: Latvijas Universitātes Raksti. Juridiskā zinātne [Scientific Papers University of Latvia. Law], Vol. 719. Rīga: Latvijas Universitāte, 2007, pp. 76-90.

6 Pagaidu nolikums par Latwijas teesam un teesaschanas kahrtibu [Provisional regulation of Latvia's courts and court procedure]. Latwijas Pagaidu Waldibas Likumu un Rihkojumu Krahjums, No. 1, 15.07.1919, pp. 12-13; Likums par agrāko Krievijas likumu spēkā atstāšanu Latvijā [Law on the former Russian laws' continued application in Latvia]. Likumu un valdības rīkojumu krājums, No. 13, 31.12.1919, p. 170.

7 Extensively on the local an social particularism, casuistry and need of modernisation Schwartz, $P$. Das Lettländische Zivilgesetzbuch vom 28. Januar 1937 und seine Entstehungsgeschichte [The Latvian Civil Code of 28 January 1937 and its historical origin]. Aachen: Shaker Verlag Verlag, 2008, pp. 235-244.

8 For an overview on the different parts of the marriage law and how they were included in the Baltic Provincial Law Code, the Marriage Act of 1921 and the Civil Code of 1937 see Schwartz, P. Das 
"Groundwork" might be too modest a designation to do justice to the substantial regulation of certain legal fields as, e.g., the Marriage Act of $1921 .{ }^{9}$ Even if this Marriage Act in 1921 did not encompass all the areas of marriage law (it did not address engagement, matrimonial property scheme and personal rights of the spouses), it was a substantial step forward in the creation of a new and country's own civil code. Furthermore, three drafts covering the missing aspects were prepared in 1921, 1929/30 and $1932^{10}$, reflecting a very vivid discussion on the matrimonial property regime for the young Republic of Latvia with the foreseen statutory matrimonial property scheme changing from draft to draft. ${ }^{11}$

Different key players were involved throughout these nearly 20 years of codification work. The elected deputies of the Constitutional Assembly (1920-1922) worked out and adopted the Marriage Act of 1921. Three Codification Committees (1920-1923, 1924, 1933-1936), all chaired by Vladimir Bukovsky (1867-1937) and gathering respected legal experts from different (national) backgrounds, elaborated the draft Latvian Civil Code. ${ }^{12}$ Since the Latvian Parliament had been dissolved as result of the coup d'état in 1934 by the then Prime Minister Kārlis Ulmanis (18771942), the draft Latvian Civil Code was handed over at the end of May 1936 to the Cabinet of Ministers. The codification work was finalised in the so-called Small Cabinet of Ministers ${ }^{13}$ and the Latvian Civil Code adopted by the regular Cabinet of Ministers on 28 January 1937.

The codification work on the Latvian Civil Code of 1937 and its marriage law is a good reflection of 20 years of discussion on the best civil and hence also best marriage law for the young Republic of Latvia. Furthermore, it provides an

Eherecht der jungen Republik Lettland 1918-1940 [The marriage law of the young Republic of Latvia 1918-1940]. In: Kulturkampf um die Ehe. Löhnig, M. (ed.). Tübingen: Mohr Siebeck, 2020, pp. 269-271.

Extensively on the Latvian Civil Code of 27 January 1937 and its codification history: Schwartz, P. Das Lettländische Zivilgesetzbuch vom 28. Januar 1937 ...; Švarcs, F. Latvijas 1937. gada 28. janvāra Civillikums un tā rašanās vēsture [The Latvian Civil Code of 28 January 1937 and its historical origin]. Rīga: Tiesu namu aǵentūra, 2011; Schwartz, P. Das Lettländische Zivilgesetzbuch von 1937 [The Latvian Civil Code of 1937]. In: „Nichtgeborene Kinder des Liberalismus“? Zivilgesetzgebung im Mitteleuropa der Zwischenkriegszeit. Löhnig, M., Wagner, S. (eds.). Tübingen: Mohr Siebeck, 2018, pp. 317-358.

9 Likums par laulibu [Marriage Act]. Likumu un waldibas rihkojumu krahjums, No. 5, 28.02.1921, pp. 91-96; Papildinajums pee likuma par laulibu [Addendum to the Marriage Act]. Likumu un waldibas rihkojums krahjums, No. 9, 21.05.1921, p. 146, with a supplement on 27 April 1921 to Art. 63.

10 Likumprojekts par saderināšanos, laulāto personiskām un mantiskām attiecībām un viṇu mantošanu [Draft law on the Engagement, matrimonial property regime and inheritance law of the spouses] (1921). Tieslietu Ministrijas Vēstnesis, No. 5(3), 1924, pp. 101-116; Likums par gimenes tiesībām. Projekts [Family Law. Draft] (1929/ 30). Tieslietu Ministrijas Vēstnesis, No. 13(1/2), 1932, pp. 1-29. Reform of the matrimonial property regime and the personal rights of the spouses (1932) published as part of the draft: Civillikumi. Pirmā grāmata. G̦imenes tiesības. Projekts [Civil Law. First Book. Family Law. Draft]. Tieslietu Ministrijas Vēstnesis, No. 15(9/10), 1934, pp. 233-284 (the provisions on the engagement and the matrimonial property regime nearly matching word-for-word the draft from 1921).

11 Schwartz, P. Das Eherecht ..., p. 278.

12 On the (composition of the) different codification committees and their individual members: Schwartz, P. Das Lettländische Zivilgesetzbuch von 1937, pp. 333-342.

13 The Small Cabinet of Ministers had the task to prepare proposals and draft laws respectively to assess from a legal and technical perspective draft laws and draft decisions submitted to the Cabinet of Ministers. Its composition was decided on a case-by-case basis. On the Small Cabinet of Ministers: Schwartz, P. Das Lettländische Zivilgesetzbuch vom 28. Januar 1937 ..., pp. 124-125 (esp. footnote 503). 
image of the changing views and values in the Latvian society between 1918 and 1937. When looking at the marriage law and its key aspects, it would therefore be too simplistic to confine the current review to the Civil Code of 1937 in its final shape and to compare it with the pre-independence legal system before 1918. It is much more honest and rewarding to look at the 20 years of legislative work, of legal developments and societal discussions between 1918 and 1937. With the preindependence legal system before 1918 as starting point and the Latvian Civil Code of 1937 as endpoint.

There are four key aspects which very well characterise the discussions and legislative work on the marriage law during these 20 years. A discussion between old and new, between traditional and modern, between strict and liberal. Four key issues found their final answer in the Latvian Civil Code of 1937: first of all, the decision between retaining the confessional marriage law or introducing a new civil marriage law; secondly, a more general choice between individual interest (of the spouses) and common interest (of the society and the state); thirdly, a choice between preserving a patriarchal marriage law and developing a marriage law based on gender equality. And, last but not least, the choice between a strict conservative matrimony or a modern liberal marriage, and especially - divorce law. ${ }^{14}$

\section{Confessional v. Civil Marriage Law}

The Marriage Act of 1921 replaced the confessional marriage law (Art. 1-4, Baltic Provincial Law Code $)^{15}$ with a civil marriage law, introducing the facultative civil marriage as its main symbol (Art. 24 Marriage Act of 1921). ${ }^{16}$ It was now left at the discretion of the spouses to choose whether they wanted to get married in church or at the civil registry office. While the marriage ceremony could take place either in church or at the civil registry office, in order for the marriage to be legally effective, it had to be registered at the civil registry office (according to the Law on Registration of Civil Status Documents of 1921). This led to a heated discussion between the defenders of the confessional marriage and the supporters of the civil marriage. The conflict mainly concerned the question whether the church wedding should be only a ceremony without a legal effect, or if the right to register the marriage could also be given to the priest. The opposition against the registration of the marriage only at the civil registry office was especially strong in the Catholic part of Latvia, namely, the south-eastern region of Latgale. With $32.21 \%$ of the total population in Latvia in 1920 the (Roman and Greek) Catholics were the second biggest confession after the Evangelical Lutherans. making up $57.29 \% .^{17}$ In their

14 For a detailed presentation of the substantive marriage law: Lettlands Zivilgesetzbuch vom 28. Januar 1937 in Einzeldarstellungen. Erster Band: Einleitung - Familienrecht - Erbrecht [Latvia's Civil Code of 28 January 1937 in individual presentations. First volume: Introduction - Family law - Heritage Law]. Herderinstitut zu Riga (ed.). Riga: Ernst Plates, 1938, pp. 139-232; Schwartz, P. Das Lettländische Zivilgesetzbuch vom 28. Januar 1937 ..., pp. 164-186 (with extensive references).

15 Provinzialrecht der Ostseegouvernements, dritter Theil, Liv-, Est- und Curländisches Privatrecht, zusammengestellt auf Befehl des Herrn und Kaisers Alexander des II. [Baltic Provincial Law Code, third Part, Private law of Livonia, Estonia and Courland, compiled by the order of Emperor Alexander II.] St. Petersburg, 1864.

16 Worth adding - Art. 10 Marriage Act of 1921, according to which judgements by former ecclesial courts concerning the legal prohibition of a marriage lost their validity. Hereinafter, the exclusive jurisdiction for marital matters was in the responsibility of the secular courts.

17 23.51\% Roman Catholics and 8.70\% Greek Catholics in addition to (in 1920) 4.99\% Jews, 4.59\% Old Believers, $0.61 \%$ other protestants and $0.31 \%$ other confessions respectively unknown. See Skujenieks, 
fight for the confessional marriage and the right for the church to also be entitled to registering the marriage, its supporters used both parliamentary means and, already at that time, mass media. Their resistance to the registration exclusively at the civil registry office took the form that could be considered civil disobedience, shunning the set rules. This eventually led to an amendment to the Law on Registration of Civil Status Documents of 1921, which was introduced in 1928, conferring the right to register the marriage both upon the state and the church. ${ }^{18}$

\section{Individual v. Common Interest}

The introduction of the facultative civil marriage and the opportunity for the spouses to freely choose between a wedding at the civil registry office or in church was a first step to emancipate the spouses not only from confessional, but also from social and legal expectations and limitations. It was complemented by giving the spouses the possibility to getting divorced by agreement (Art. 51 Marriage Act of 1921) or based on the principle of irretrievable breakdown as sufficient grounds for divorce (Art. 49 Marriage Act of 1921). And when the Civil Code of 1937 introduced the engagement in its para. 26 (and in para. 27 - the possibility to withdraw from it), it was now a free decision of the spouses to enter the matrimony.

All these new possibilities very much took into account the individual interest of husband and wife. Furthermore, it can be asserted that introducing the facultative civil marriage and a simplified divorce was a step towards individual interest gaining centre stage instead of community and common interest. However, there was no linear development from these first steps in the Marriage Act of 1921 until the Civil Code of 1937 with the one extreme (individual interest) simply replacing the other extreme (common interest). On the one hand, the contraction of marriage, as well as the liberal divorce law as introduced by the Marriage Act of 1921 brought the individual and individual interest into focus. On the other hand, the Civil Code of 1937 rather places an emphasis upon the community and the common interest. ${ }^{19}$

The overall change towards the common interest must be observed in the historical and political context and development in Latvia, especially in the second half of the 1930s. On 15 May 1934, the then Prime Minister Kārlis Ulmanis (1877-1942) came into power by a coup d'état and established an authoritarian regime. The communities - family, nation and state - gained centre stage, and the understanding of the family as the basic unit of nation and state was also expressed in the Civil Code of 1937. Firstly, the family was confirmed as one of the four leading civil law principles besides succession, private property and freedom

M. (red.). Otrā tautas skaitǐšana Latvijā. 2. daḷa [Second census of population in Latvia. $2^{\text {nd }}$ Part]. Rīga: Valsts statistiskā pārvalde, 1925, p. 76.

18 Pārgrozījumi un papildinājumi likumā par civilstāvokḷa aktu reǵistrāciju [Amendments and addenda to the Law on Registration of Civil Status Documents]. Likumu un Ministru kabineta noteikumu kräjums, No. 5, 27.03.1928, pp. 62-63. In more details about this development (with further references) Lipša, I. Restriction of Freedom of Consciousness in Democracy: Catholic Protests against the Law on Registry of Civil Status in Latvia (1921-1928). Istorija, No. LXXXIV/84, 4, 2011, pp. 78-81; Lipša, I. Sabiedriskā tikumība Latvijā demogrāfisko problēmu aspektā, 1918-1940 [Public morality in Latvia in the facet of problems of demography, 1918-1940]. Latvijas Vēstures Institūta Žurnāls, No. 70(1), 2009, pp. 68-70.

19 Bümanis, A. Vispārējs pārskats par jauno Civillikuma [General overview of the new Civil Code]. In: Prezidenta Ulmaṇa Civillikums (rakstu krājums). Rīga: Pagalms, 1938, pp. 99-100. 
of contract. ${ }^{20}$ Secondly, in the order of the different fields of law in the Civil Code of 1937, which reflects these four leading principles, the Civil Code literally puts the family law in the first place (First Part, paras 26-381), immediately after the 25 articles of the introduction and collision regulations - a general part was completely missing. It is followed by the heritage law (paras 382-840), property law (paras 841-1400) and law of obligations (paras 1401-2400). This is actually the same order which Krišjānis Barons (1835-1923) had used for his collection of dainas (four-line Latvian folk songs). However, constitutional protection of the family is provided only since 1998 when an up-to-then missing catalogue of fundamental rights (here - Article 110) was included in the Latvian Constitution of $1922 .^{21}$

At the same time, the Civil Code of 1937 and its marriage law also introduced (engagement) and retained (facultative civil marriage, liberal divorce law) those provisions which rather focussed on the individual and individual interest. By understanding the marriage as alliance built on mutual trust, which should not be artificially and compulsively preserved if the basis for such alliance, the mutual trust between the spouses, is lost, ${ }^{22}$ hereby giving priority to the individual interest of the spouses (to dissolve their marriage) instead of the common interest (to preserve the marriage, the family as the basic unit of the state).

Hence, the family and marriage law created a balance between individual and common interest. Or, as the jurist and son of the first Latvian State President Jānis Čakste (1859-1927) Konstantīns Čakste (1901-1945) wrote:

Every civil law institution contains individual and social elements which recognise the interests of the society. The marriage is no exception. Therefore, also in the family law the institution of marriage as well as other family law institutions have to be shaped on the basis of these two principles, a certain synthesis has to be formed. ${ }^{23}$

\section{Patriarchal Marriage Law v. A Marriage Law Based on Gender Equality}

While the Marriage Act of 1921 introduced significant and progressive changes to the pre-independence approach (facultative civil marriage, divorce by agreement, introduction of the principle of irretrievable breakdown as sufficient grounds for divorce), it did not fundamentally change the legal status of women. As the Marriage Act of 1921 did not contain any specific provisions on the legal status of women, the old patriarchal legal situation inherited from pre-independence times continued to determine the legal status of women. ${ }^{24}$ Likewise, the Constitution did not provide constitutional protection of gender equality as the catalogue of

20 Būmanis, A. Vispārējs pārskats par jauno Civilllikuma [General overview of the new Civil Code]. In: Prezidenta Ulmaņa Civīllikums (rakstu krājums). Rīga: Pagalms, 1938, pp. 99-100. pp. 99-101.

21 Art. 110 of the Latvian Constitution reads "The State shall protect and support marriage - a union between a man and a woman, the family, the rights of parents and rights of the child. [..]" Available: https://likumi.lv/ta/id/57980-latvijas-republikas-satversme [in Latvian, last viewed 07.02.2021] or https://likumi.lv/ta/en/id/57980-the-constitution-of-the-republic-of-latvia [in English, last viewed 13.02.2021].

22 Apsīts, H. Jaunais civīllikums [The new Civil Code]. In: Prezidenta Ulmaṇa Civillikums, pp. 90-91.

23 Cakste, K. Civiltiesïbas. Lekcijas. Raksti [Civil Law. Lectures. Articles]. Rīga: Zvaigzne ABC, 2011, pp. 198-199.

24 On the legal status of women before and (immediately) after Latvia had gained independence in 1918: Osipova, S. Sieviešu tiesības Latvijā 1918-1940: starp politisko pilntiesību un civiltiesisko 
fundamental rights had not been adopted in 1922. The drafted, but not adopted Part 8 of the Latvian Constitution on the fundamental rights would have foreseen equal rights of men and women in general (Art. 87) and with regard to the marriage (Art. 114). ${ }^{25}$

The first steps towards an improved, more equal legal status of women were, however, considered already before, for example, the suggested limitations to the guardianship of the husband (so far stipulated in Art. 11 of Baltic Provincial Law Code) in the aforementioned draft law on "Engagement, matrimonial property regime and inheritance law of the spouses" $(1921)^{26}$ or the idea in the mid-1920s to have a statutory matrimonial property scheme (separation of property with administration and usufruct by the husband) built on the principles of usufruct and not on a lower status of the wife. ${ }^{27}$

A real change in the legal status of women was only achieved with the Civil Code of 1937, which liberated the wife from the guardianship of her husband. From now on, with the Civil Code entering into force on 1 January 1938, both spouses had the same rights (para. 85 subpara. 1 sentence 1). However, in case both could not agree, the husband still had the deciding vote (para. 85 subpara. 1 sentence 2 ). ${ }^{28}$ At the same time, the wife got the right to administer the household and the power to represent her husband in matters concerning the household (para. 87 subpara. 1). An improvement in the legal status of women can also be seen in the specific property which is excepted from the administration und usufruct by the husband (paras 90 subpara. 1,91 ) or the now equality of husband and wife when it comes to the obligation to pay alimony after the dissolution of the marriage (paras 79, 81).

While these are considerable steps towards an improved, more equal legal status of women the Latvian Civil Code of 1937 included and still includes also provisions which rather preserve the old role model of men and women. Although "the dowry was already in the moment of the adoption of the Civil Code an archaic legal institution", paras 111-113 Latvian Civil Code of 1937 (still today) regulate the dowry $^{29}$ "as a legal institute characteristic for the Latvian national law". ${ }^{30}$ Likewise,

nevienlīdzību [Women's Rights in Latvia 1918-1940: Between Equality in Political Rights and Civil Inequality]. Journal of the University of Latvia. Law, No. 8, 2015, pp. 114-115.

25 Available (document 28) in Lazdinšs, J., Kučs, A., Pleps, J., Kusiňš, G. (eds.). Latvijas valsts tiesību avoti. Valsts dibināšana - neatkarības atjaunošana. Dokumenti un komentāri [The sources of law of the Latvian state. Founding of the state - restoration of independence. Documents and commentaries]. Rīga: Tiesu namu aǵentūra, 2015, pp. 124-126.

26 Osipova, S. Sieviešu tiesibas ..., pp. 118-119.

27 Bukowsky, W. Zur Frage des Systems des ehelichen Güterrechts in Lettland [On the question of the matrimonial property regime]. Rigasche Zeitschrift für Rechtswissenschaft, Nr. 1(4), 1926/1927, p. 254.

28 Čakste, K. Civiltiesibas, p. 206, actually argues that the reason for giving preference to the husband's voice is not based on his guardianship. But derives from the nature of the marriage with the husband more participating in social life and hence having more practical experience than his wife.

29 For an extensive examination of the dowry including the question of its conformity with the Latvian Constitution in view of the principle of gender equality see the 2018 doctoral thesis by Nikolajeva, $I$. Laulāto mantisko attiecību institūta - pūra - vēsturiskā evolūcija un vieta mūsdienu kontinentālo tiesību saimē [Historical evoluation of the institution of pecuniary relationship of spouses - dowry and place in the family of modern continental law]. Riga, 2018. Summary available in English: https:// www.turiba.lv/storage/files/synopsis-nikolajeva.pdf and in Latvian: https://www.turiba.lv/storage/ files/kopsavilkums-nikolajeva.pdf.

30 Referring to Arveds Švābe (1888-1959): Osipova, S. Familienrecht in der Republik Lettland im XX-XXI Jahrhundert [Family law in the Republic of Latvia in the XX-XXI century]. In: Kieler Ostrechts-Notizen, Schwerpunkt Recht der Baltischen Staaten. Institut für Osteuropäisches Recht der Universität Kiel (ed.). Kiel: Institut für Osteuropäisches Recht der Universität Kiel, 2012 (15. Jahrgang), 1-2, p. 50; Osipova, S. Sieviešu tiesibas ..., p. 121. 
the statutory matrimonial property scheme which was ultimately chosen for the Latvian Civil Code of 1937, the "administration and usufruct", in para 90 subpara. 1 still stipulated that the husband had the right to administer and usufruct both the wife's premarital property and the property the wife had acquired during the marriage (but with an exception of specific property).

This development towards a more equal legal status of women was not welcomed unanimously. ${ }^{31}$ However, although some contemporaries were of the opinion that this development went too far, from today's point of view it was not all that advanced and one can hardly speak about a complete gender equality in the Latvian Code of 1937. The Latvian Civil Code of 1937 rather preserved the patriarchal family, although in a liberalised form. ${ }^{32}$ The next steps towards gender equality in the Civil Code were taken only as it was reinstated and amended after Latvia had regained independence in 1990/91. ${ }^{33}$

\section{Till Death Do Us Part v. A Modern and Liberal Divorce Law}

The changes to the divorce law introduced by the Marriage Act of 1921 were quite radical and progressive for their time, with the new divorce law being in total contradiction to the former confessional marriage law. Following the example of the Swiss Civil Code of $1907,{ }^{34}$ which together with the Swiss Code of Obligations of 1911 and the German Civil Code of 1896 were the main foreign codes of law influencing the Latvian Civil Code of 1937, the latter introduced the principle of irretrievable breakdown as sufficient grounds for divorce (Art. 49). By introducing the divorce by agreement (Art. 51), the Civil Code of 1937 substantially facilitated the dissolution of the marriage. ${ }^{35}$ The secular and no longer confessional court only had to examine whether the joint application for divorce satisfied all the procedural requirements. It did not matter, and the court did not examine the reasons or the question of fault. Moreover, the spouses did not even have to reveal the reasons for the failure of their marriage. Clearly, it might have been comfortable for the spouses not to have to disclose the real reasons for the failure of their marriage.

What were the reasons behind introducing such a radical and progressive divorce law? It had to do with the understanding of the marriage as a union built on mutual trust of the spouses. Such union built on trust should not be artificially

31 For some examples, see Schwartz, P. Das Eherecht ..., p. 293.

32 Osipova, S. Sieviešu tiesības ..., p. 121.

33 Ciematniece, I. Laulāto mantisko attiecību regulējums Latvijā [The regulation of property relations of spouses in Latvia]. Jurista Vārds, No. 20, 27.05.2008; No. 21, 03.06.2008, Chapter 2 (available as online article from www.juristavards.lv without page numbers).

34 Schwarz, A. B. Das Schweizerische Zivilgesetzbuch in der ausländischen Rechtsentwicklung [The Swiss Civil Code in foreign legislative trends]. Zürich: Schulthess \& Co. A.G., 1950, p. 46; Berent, B. Schliessung und Auflösung der Ehe [Contraction and rescission of marriage]. In: Lettlands Zivilgesetzbuch vom 28. Januar 1937 in Einzeldarstellungen. Erster Band: Einleitung Familienrecht - Erbrecht [Latvia's Civil Code of 28 January 1937 in individual presentations. First volume: Introduction - Family law - Heritage Law]. Herderinstitut zu Riga (ed.). Riga: Ernst Plates, 1938, p. 168 (footnote 1).

On the influence of foreign codes of law on the Latvian Civil Code of 1937 briefly Schwartz, P. Das Lettländische Zivilgesetzbuch vom 28. Januar 1937 ..., p. 153.

35 Extensively on the(se) grounds for divorce: Opss, L. Laulības šķiršanas iemesli pēc laulïbas lik. 49., 50. un 51. pantiem [The grounds for divorce according to Art. 49, 50 and 51 Marriage Act]. Rìga, 1937. On the Latvian liberal marriage (and divorce) law introduced by the Marriage Act of 1921 and similar developments in other countries: Schwartz, P. Das Eherecht ..., pp. 297-298. 
and compulsively maintained, once the trust is gone. ${ }^{36}$ It is obvious that this way of thinking had its origin also in the experiences of the First World War as referred to in the Constitutional Assembly on 10 December 1920:

During the current era when we have experienced the years of war, refugee times, when a husband and wife sometimes have been totally separated for a long time and have got alienated from each other to such degree what no cohabitation is possible. ${ }^{37}$

Although some might have feared otherwise, in the years immediately after introducing this modern and liberal divorce law in 1921, it did not immediately lead to an excessive and careless recourse to an easy divorce. But in the mid-1930s, the number of divorces was very high and different measures were taken to counteract this development (i.a. by increasing the divorce fees). ${ }^{38}$ At the same time, such simplified ways to dissolve the marriage appealed also beyond national borders, as it was sufficient to have one's registered place of residence in Latvia to make use of these simplified options. Art. 1 of Marriage Act of 1921 stipulated that it and, hence, the simplified divorce options applied to all inhabitants of Latvia, and not only to the nationals of this country. The Austrian actor and stage director Max Reinhardt (1873-1942) was most probably the most prominent "divorce tourist". In 1931, Reinhardt changed his place of residence to Riga and one week later filed for divorce - with success. ${ }^{39}$

\section{Summary}

Naturally, what the one praises as the right development towards a modern, progressive and liberal marriage law, another criticises as too liberal or radical. ${ }^{40}$ Furthermore, while for some the new provisions were overly liberal and radical, others supported even more radical changes, ${ }^{41}$ like introducing the mandatory and not only facultative civil marriage fully replacing the church marriage, ${ }^{42}$ or the divorce on demand of a single spouse without the need to indicate any reason for divorce, which was originally included in the draft Marriage Act of 1921 (but later rejected during the third reading of the draft law). ${ }^{43}$

As mentioned above, vivid and strong discussions and reactions to new laws, court decisions or, more generally, regarding legal developments are not uniquely characteristic to our time and the phenomenon of social media. Already 100 years

36 Apsìts, H. Jaunais civillikums, pp. 90-91.

37 Minutes from the Constitutional Assembly on 10 December 1920 quoted in Lipša, I. Restriction of Freedom ..., p. 76.

38 In greater detail - Schwartz, P. Das Eherecht ..., pp. 300-301.

39 On the causa Max Reinhardt, in greater detail (with further references) - ibid., pp. 301-302.

40 Schilling, C. von. Lettlands neues Zivilgesetzbuch [Latvia's new Civil Code]. Zeitschrift für Ausländisches und Internationales Privatrecht, Nr. 11, 1937, p. 492; Stegman, H. Zur Entwicklung des lettländischen Zivilrechts, 1918-1928 [On the development of the Latvian civil law, 1918-1928]. In: Baltische Rechtsangleichung, 10 Jahre Gesetzgebung Estlands und Lettlands, Referate der I. Baltischen Juristenkonferenz zu Dorpat (1928). Reval: F. Wassermann, 1929, p. 42.

41 Schwartz, P. Das Eherecht ..., pp. 298-300.

42 During the discussions of the Marriage Act of 1921, this idea was supported by the Social Democrats and the mandatory civil marriage included in its first preliminary draft. On this Osipova, S. Sieviešu tiesības ..., p. 117; Stegman, H. Zur Entwicklung ..., p. 28.

While the mandatory civil marriage did not become reality during the years 1918-1940, it was then introduced in during the Soviet Occupation of Latvia: Lazdiņš, J. Die Entstehung ..., p. 84.

43 With further references Schwartz, P. Das Eherecht ..., pp. 298-299. 
ago, the codification work on the marriage law led to controversies, as it touched upon and questioned the prevailing views and values. In some cases, criticism and opposition to new regulations lead to changes re-introducing the previous provisions. For example, in 1928 such case was granting the right to register a marriage also to the priests and not only the civil registry office, as originally foreseen in 1921. At the same time, the common understanding on certain issues can change over time, especially during legislative work spanning a longer period, like the preference for the statutory matrimonial property scheme changing over the years, as shown above. Consequently, the marriage law is very much a mirror of a society's (changing) value system.

This article demonstrated how the marriage law is betwixt and between the past and the present on the one hand, and the future on the other hand, where the discussions around the marriage law, whether the one in force or the one to be drafted, are an indicator and benchmark for the different opinions and moral values in the society. The article also showed and substantiated that the marriage law is betwixt and between those who want to preserve the status quo and those who aim to go a step further by adapting the marriage law to what they perceive to be the new and different reality. How the marriage law is betwixt between following legal and societal developments on the one hand, and playing a leading role in developing the civil law further on the other hand - possibly serving as inspiration for other countries. ${ }^{44}$ The current article also reveals how the marriage law and especially its drafts are betwixt and between being considered from an ex-ante perspective as too radical and progressive, while from an ex-post perspective - as modern and liberal, a trendsetter at the time. The Latvian marriage law in the period of 1918-1940 comprehensively illustrates the challenge of being betwixt and between the poles of different moral values, and the parallels to this phenomenon can be drawn to this day.

\section{Sources}

\section{Bibliography}

1. Apsits, $H$. Jaunais civillikums [The new Civil Code]. In: Prezidenta Ulmaņa Civillikums (rakstu krājums). Rīga: Pagalms, 1938, pp. 85-96.

2. Berent, B. Schliessung und Auflösung der Ehe [Contraction and rescission of marriage]. In: Lettlands Zivilgesetzbuch vom 28. Januar 1937 in Einzeldarstellungen, Erster Band: Einleitung Familienrecht - Erbrecht. Herderinstitut zu Riga (ed.). Riga: Ernst Plates, 1938, pp. 139-187.

3. Bukowsky, W. Zur Frage des Systems des ehelichen Güterrechts in Lettland [On the question of the matrimonial property regime]. Rigasche Zeitschrift für Rechtswissenschaft, Nr. 1(4), 1926/1927, pp. $247-265$.

4. Bümanis, A. Vispārējs pārskats par jauno Civīllikuma [General overview of the new Civil Code]. In: Prezidenta Ulmaña Civillikums (rakstu krājums). Rìga: Pagalms, 1938, pp. 97-101.

5. Ciematniece, I. Laulāto mantisko attiecibu regulējums Latvijā [The regulation of property relations of spouses in Latvia]. Jurista Vārds, No. 20, 27.05.2008; No. 21, 03.06.2008.

6. Čakste, K. Civiltiesības. Lekcijas. Raksti [Civil Law. Lectures. Articles]. Rīga: Zvaigzne ABC, 2011.

7. Lazdiņš, J. Die Entstehung und Entwicklung des Eherechts in Lettland [The evolution and development of the marriage law in Latvia]. In: Latvijas Universitātes Raksti. Juridiskā zinātne [Scientific Papers University of Latvia. Law], Vol. 719. Rīga: Latvijas Universitāte, 2007, pp. 76-90.

8. Lazdinnš, J., Kučs, A., Pleps, J., Kusiņ̌š, G. (eds.). Latvijas valsts tiesību avoti. Valsts dibināšana neatkaribas atjaunošana. Dokumenti un komentāri [The sources of law of the Latvian state.

44 On the family and especially the divorce law of the Latvian Civil Code of 1937 in the context of legal developments in other (not only) European countries in that time: Schwartz, P. Das Eherecht ..., pp. 297-298. 
Founding of the state - restoration of independence. Documents and commentaries]. Rīga: Tiesu namu agèntūra, 2015, pp. 124-126.

9. Lettlands Zivilgesetzbuch vom 28. Januar 1937 in Einzeldarstellungen, Erster Band: Einleitung Familienrecht - Erbrecht [Latvia’s Civil Code of 28 January 1937 in individual presentations. First volume: Introduction - Family law - Heritage Law]. Herderinstitut zu Riga (ed.). Riga: Ernst Plates, 1938, pp. 139-232.

10. Lipša, I. Restriction of Freedom of Consciousness in Democracy: Catholic Protests against the Law on Registry of Civil Status in Latvia (1921-1928). Istorija, No. LXXXIV/84, 4, 2011, pp. 75-86.

11. Lipša I. Sabiedriskā tikumība Latvijā demogrāfisko problēmu aspektā, 1918-1940 [Public morality in Latvia in the facet of problems of demography, 1918-1940]. Latvijas Vèstures Institūta Žurnāls, No. 70(1), 2009, pp. 53-80.

12. Nikolājeva, I. Laulāto mantisko attiecību institūta - pūra - vēsturiskā evolūcija un vieta mūsdienu kontinentālo tiesību saimē [Historical evoluation of the institution of pecuniary relationship of spouses - dowry - and place in the family of modern continental law]. Riga, 2018. Summary in English: https://www.turiba.lv/storage/files/synopsis-nikolajeva.pdf and in Latvian: https://www. turiba.lv/storage/files/kopsavilkums-nikolajeva.pdf [last viewed 14.02.2021].

13. Opss, L. Laulïbas šķiršanas iemesli pēc laulības lik. 49., 50. un 51. pantiem [The grounds for divorce according to Art. 49, 50 and 51 Marriage Act]. Rìga, 1937.

14. Osipova, S. Familienrecht in der Republik Lettland im XX-XXI Jahrhundert [Family law in the Republic of Latvia in the XX-XXI century]. In: Kieler Ostrechts-Notizen, Schwerpunkt Recht der Baltischen Staaten. Institut für Osteuropäisches Recht der Universität Kiel (ed.). Kiel: Institut für Osteuropäisches Recht der Universität Kiel, 2012 (15. Jahrgang), 1-2, pp. 47-60.

15. Osipova, S. Sieviešu tiesības Latvijā 1918-1940: starp politisko pilntiesỉbu un civiltiesisko nevienlīdzïbu [Women's Rights in Latvia 1918-1940: between Equality in Political Rights and Civil Inequality]. Journal of the University of Latvia. Law, No. 8, 2015, pp. 111-125.

16. Schilling, C. von. Lettlands neues Zivilgesetzbuch [Latvia's new Civil Code]. Zeitschrift für Ausländisches und Internationales Privatrecht, No. 11, 1937, pp. 484-527.

17. Schwartz, P. Das Eherecht der jungen Republik Lettland 1918-1940 [The marriage law of the young Republic of Latvia 1918-1940]. In: Kulturkampf um die Ehe. Löhnig, M. (ed.). Tübingen: Mohr Siebeck, 2020, pp. 265-305.

18. Schwartz, P. Das Lettländische Zivilgesetzbuch vom 28. Januar 1937 und seine Entstehungsgeschichte [The Latvian Civil Code of 28 January 1937 and its historical origin]. Aachen: Shaker Verlag, 2008.

19. Schwartz, P. Das Lettländische Zivilgesetzbuch von 1937 [The Latvian Civil Code of 1937]. In: „Nichtgeborene Kinder des Liberalismus"? Zivilgesetzgebung im Mitteleuropa der Zwischenkriegszeit. Löhnig, M., Wagner, S. (eds.). Tübingen: Mohr Siebeck, 2018, pp. 317-358.

20. Schwarz, A. B. Das Schweizerische Zivilgesetzbuch in der ausländischen Rechtsentwicklung [The Swiss Civil Code in foreign legislative trends]. Zürich: Schulthess \& Co. A.G., 1950.

21. Skujenieks, M. (ed.). Otrā tautas skaitī̌ana Latvijā. 2. daḷa [Second census of population in Latvia. $2^{\text {nd }}$ Part]. Rīga: Valsts statistiskā pārvalde, 1925.

22. Stegman, H. Zur Entwicklung des lettländischen Zivilrechts, 1918-1928 [On the development of the Latvian civil law, 1918-1928]. In: Baltische Rechtsangleichung, 10 Jahre Gesetzgebung Estlands und Lettlands, Referate der I. Baltischen Juristenkonferenz zu Dorpat (1928). Reval: F. Wassermann, 1929, pp. 27-44.

23. Švarcs, F. Latvijas 1937. gada 28. janvāra Civillikums un tā rašanās vēsture [The Latvian Civil Code of 28 January 1937 and its historical origin]. Rīga: Tiesu namu aǵentūra, 2011.

\section{Normative Acts}

1. Latvijas Republikas Satversme [The Constitution of the Republic of Latvia]. Available: https://likumi. lv/ta/id/57980-latvijas-republikas-satversme [in Latvian, last viewed 07.02.2021]; https://likumi.lv/ $\mathrm{ta} / \mathrm{en} / \mathrm{id} / 57980$-the-constitution-of-the-republic-of-latvia [in English, last viewed 13.02.2021].

2. Grozijums Latvijas Republikas Satversme [Amendment to the Constitution of the Republic of Latvia]. Latvijas Vēstnesis, No. 1, 03.01.2006. Available: https://www.vestnesis.lv/ta/id/124957 [last viewed 07.02.2021].

3. Pagaidu nolikums par Latwijas teesam un teesaschanas kahrtibu [Provisional regulation of Latvia's courts and court procedure]. Latwijas Pagaidu Waldibas Likumu un Rihkojumu Krahjums, No. 1, 15.07.1919. pp. 12-13.

4. Likums par agrāko Krievijas likumu spēkā atstāšanu Latvijā [Law on the former Russian laws' continued application in Latvia]. Likumu un valdības rïkojumu krājums, No. 13, 31.12.1919, p. 170. 
5. Likums par laulibu [Marriage Act]. Likumu un waldibas rihkojumu krahjums, No. 5, 28.02.1921, pp. 91-96.

6. Papildinajums pee likuma par laulibu [Addendum to the Marriage Act]. Likumu un waldibas rihkojumu krahjums, No. 9, 21.05.1921, p. 146.

7. Likumprojekts par saderināšanos, laulāto personiskām un mantiskām attiecībām un vinu mantošanu [Draft law on the Engagement, matrimonial property regime and inheritance law of the spouses]. Tieslietu Ministrijas Vèstnesis, No. 5(3), 1924, pp. 101-116.

8. Pārgrozījumi un papildinājumi likumā par civīlstāvokḷa aktu regiistrāciju [Amendments and addenda to the Law on Registration of Civil Status Documents]. Likumu un Ministru kabineta noteikumu kräjums, No. 5, 27.03.1928, pp. 62-63.

9. Likums par ğimenes tiesỉbām. Projekts [Family Law. Draft]. Tieslietu Ministrijas Vēstnesis, No. 13(1/2), 1932, pp. 1-29.

10. Civillikumi. Pirmā grāmata. Ģimenes tiesības. Projekts [Civil Law. First Book. Family Law. Draft]. Tieslietu Ministrijas Vēstnesis, No. 15(9/10), 1934, pp. 233-284.

11. Provinzialrecht der Ostseegouvernements, dritter Theil, Liv-, Est- und Curländisches Privatrecht, zusammengestellt auf Befehl des Herrn und Kaisers Alexander des II. [Baltic Provincial Law Code, third Part, Private law of Livonia, Estonia and Courland, compiled by the order of Emperor Alexander II.] St. Petersburg, 1864.

\section{Case Law}

1. Judgement of the Constitutional Court of Latvia of 12 November 2020 in case No. 2019-33-01 "Par Darba likuma 155. panta pirmās daļas atbilstību Latvijas Republikas Satversmes 110. panta pirmajam teikumam" ["On the conformity of Art. 155 First Paragraph Labour Law with Art. 110 First Sentence of the Constitution of the Republic of Latvia"]. Available: https://www.satv.tiesa.gov. lv/wp-content/uploads/2019/12/2019-33-01_Spriedums-3.pdf [last viewed 03.02.2021]. 